\title{
Effect of ammonium chloride and urea infusions on ammonium levels and acidity of gastric juice ${ }^{1,2}$
}

\author{
BERTRAM FLESHLER AND GEORGE J. GABUZDA \\ From the Department of Medicine, Western Reserve University School of \\ Medicine at Cleveland Metropolitan General Hospital, \\ Cleveland, Ohio, U.S.A.
}

EDITORIAL SYNOPSIS The evidence presented here favours the possibility that gastric ammonium is produced from the urea in the blood through the action of a non-bacterial gastric urease. It also originates from blood ammonium which is transferred from blood into the gastric juice, the amount depending upon the level of the blood ammonium and the $\mathrm{pH}$ gradient between blood and gastric juice and the state of gastric secretion.

Ammonium levels in gastric juice are higher than those in blood. The concentrations of ammonium in gastric juice are measured in hundreds of micrograms ( $\mu$ g.) to milligrams (mg.) per $100 \mathrm{ml}$. (Kornberg and Davies, 1955; FitzGerald and Murphy, 1950; Mossberg, Thayer, and Spiro, 1963; Rappoport and Kern, 1963) whereas blood ammonium levels normally are less than $100 \mu \mathrm{g} \%$. (Gabuzda, 1962). That gastric juice ammonium is derived from blood urea nitrogen through the action of gastric urease has been generally accepted, although whether the urease is bacterial or non-bacterial in origin remains unsettled (Kornberg and Davies, 1955; Conway, FitzGerald, McGeeney, and Geoghegan, 1959; Bessman and Stauffer, 1957). However, several observations are difficult to reconcile with the concept that gastric juice ammonium is derived from blood urea nitrogen. For example, wide ranges of values for gastric juice ammonium levels have been reported in human subjects and in animals with normal blood urea levels (Kornberg and Davies, 1955; Mossberg et al., 1963; Rappoport and Kern, 1963). Although a linear relation between blood urea nitrogen concentrations and ammonium levels in gastric juice has been demonstrated with data obtained from animal experiments (Von Korff and Glick, 1951 ; Von Korff, Ferguson, and Glick, 1951), elevations in blood urea resulting from intravenous

'Presented in part at the Gastroenterology Subspecialty Meeting under joint sponsorship of the American Federation for Clinical Research and the American Society for Clinical Investigation, Atlantic City, New Jersey, 29 April 1962.

'This investigation was supported in part by grant no. A-4012, National Institute of Arthritis and Metabolic Diseases, and in part by the Research and Development Division, Office of the Surgeon General, Department of the Army, under contract no. DA-49-007MD-749. urea infusions did not cause predictable increases in gastric juice ammonium levels in man (Mossberg et al., 1963). Furthermore, gastric urease activity cannot be demonstrated in certain animal species (Kornberg and Davies, 1955).

The hypothesis that blood ammonium is another source of gastric juice ammonium also has been considered but rejected (Bessman and Stauffer, 1957). The present study was designed as a further test of this hypothesis. The effects of ammonium chloride and of urea infusions on gastric juice ammonium levels were compared in human subjects. Some subjects were also pretreated with neomycin to decrease the possible effect of bacterial urease. The results of our studies show that ammonium of gastric juice may be derived, in part at least, from blood ammonium. Because of the possible role of ammonium in neutralizing gastric acid (Lieber and Lefèvre, 1959), the effects of varying levels of blood and gastric juice urea and ammonium on gastric acidity were also evaluated.

\section{METHODS}

The effects of betazole hydrochloride (Histalog ${ }^{3}$ ) and of ammonium chloride $4\left(\mathrm{NH}_{4} \mathrm{Cl}\right)$ and urea ${ }^{5}$ infused intravenously on $p \mathrm{H}$, volume, and ammonium and urea nitrogen levels of gastric juice were determined. The influence of pretreatment with oral neomycin was also tested. Thirty-four adult hospital in-patients without evident hepatic, gastrointestinal, or renal disease, and two patients with pernicious anaemia were the subjects of these investigations. The following studies were done.

${ }^{8}$ Eli Lilly and Company.

$\cdot 2 \cdot 14 \% \mathrm{NH}_{4} \mathrm{Cl}$, Cutter Laboratories.

'Urevert (30\% in $10 \%$ invert sugar), Travenol Laboratories. 
The effect of betazole hydrochloride alone following a 30-minute control period was determined in nine subjects. In each of the other 27 subjects an indwelling needle was placed in the brachial artery and an intravenous infusion of saline was started. Saline was infused for an initial 30-minute control period followed by infusion of either ammonium chloride or urea during a two-hour period. After one hour of the test infusion, betazole hydrochloride, 50-75 mg., was administered intramuscularly. Seven subjects were given ammonium chloride, and eight were given urea. Ten other subjects (ammonium chloride in four, urea in six) were given neomycin sulphate, $4 \mathrm{~g}$. daily orally for four days, before each study. The effect of ammonium chloride given intravenously was also studied in two patients with pernicious anaemia and gastric anacidity. These patients did not receive antibiotics.

Each subject was intubated with a nasogastric tube following a 12-hour period of fasting. Gastric samples consisted of the total volume of juice collected by aspiration during 30-minute periods. In the subjects receiving betazole hydrochloride alone, one sample was collected before and two after betazole hydrochloride administration. In the subjects receiving ammonium chloride or urea infusions, one sample was collected initially while saline was infused, two during the test infusion, and two while the test solutions were continued after betazole hydrochloride was given. Each subject used a sputum cup throughout the study to decrease contamination of gastric juice with saliva. In an effort to obtain complete collections, the suction apparatus was observed continuously, suction interrupted frequently, and the system flushed with air.

Gastric juice for ammonium nitrogen determinations was aspirated into cold $20 \%$ trichloracetic acid ${ }^{6}$, a collection method similar to that used by Nathan and Rodkey (1957) for blood. The trichloracetic acid-treated gastric juice samples were centrifuged at 2,000 r.p.m. for 20 minutes and ammonium nitrogen $\left(\mathrm{NH}_{4} \mathrm{~N}\right)$ content determined in triplicate on aliquots of the supernatant fluid by a modification of the Conway diffusion technique (Conway, 1957; Webster, Davidson, and Gabuzda, 1958). In this procedure ammonium is liberated by alkali from the solution to be analysed. The $p H$ of the mixture of alkali and the acidified supernatant fluid was greater than 11; thus, alkalinization was sufficient to volatilize completely ammonium from the acid medium. Aliquots of the same supernatants of the acid-treated gastric juice were analysed for urea nitrogen content using the diacetylmonoxime method (Rosenthal, 1955). Arterial blood samples obtained at the beginning of the study and following each 30-minute period were analysed for ammonium nitrogen content by a modified Conway method (Conway, 1957; Webster et al., 1958) and for

\footnotetext{
-The values for gastric juice ammonium concentrations reported here are, in general, less than those reported by others (Lieber and Lefère, 1959). During the course of this study, it was observed that the measureable ammonium content of freshly aspirated samples of gastric juice allowed to stand at room or refrigerator temperatures increased with time. For this reason, the procedure of aspirating the gastric juice samples directly into cold trichloracetic acid was adopted. Values reported by Rappoport and Kern (1963), who also used a technique in which samples were immediately iced, are similar to those reported here.
}

blood urea nitrogen by the diacetylmonoxime method adapted to an autoanalyzer (Skeggs, 1957).

At the start of the study and following each 30-minute period, aliquots of gastric juice were collected separately for determination of $p \mathrm{H}$. Gastric juice $p \mathrm{H}$ was determined with a radiometer $p \mathrm{H}$ meter 22 using a glass electrode calibrated against standard buffers of low $p \mathrm{H}$ at room temperature. The $p \mathrm{H}$ values were read to the second decimal place and converted to hydrogen ion concentration $(\mathrm{H}+) \mathrm{mEq} . / \mathrm{l}$. In making this conversion the differences between $(\mathrm{H}+)$ and the activity of hydrogen ions as determined with the glass electrode were taken into account (Moore, 1963). For these calculations the activity coefficients for pure solutions of $\mathrm{HCl}$ in water at $25^{\circ} \mathrm{C}$. were used (Glasstone and Lewis, 1960). The applicability of these coefficients to gastric juice and the mixture of ions and miscellaneous substances it contains may be questioned. However, the use of these coefficients permits a more adequate approximation of true $(\mathrm{H}+)$ (Moore, 1963).

\section{RESULTS}

CONTROL DATA Control data obtained from study of subjects given only betazole hydrochloride and from the other subjects during saline infusion are shown in Table I. The observations applying to the 'no antibiotic' study group provide estimates of control values for the gastric juice and blood constituents in an adult hospital population. These observations were made under standardized conditions; however, wide ranges of values for volume, $p \mathrm{H}$, and ammonium nitrogen content of gastric juice were noted. The data obtained during the control periods were generally comparable for all the groups listed in Table I. The average gastric juice and blood ammonium levels were higher in the group not pretreated with antibiotic and subsequently given ammonium chloride, but there was considerable overlap of these values with those for the other groups. The reasons for these differences are not apparent; they may reflect a broad range of normal values.

The urea nitrogen content of gastric juice usually amounted to one-half to two-thirds that found simultaneously in blood. The ammonium nitrogen concentrations of gastric juice were not related clearly either to blood urea or blood ammonium nitrogen levels within the normal range.

Comparison of the subjects pretreated with neomycin with those not given antibiotic demonstrates the following. The gastric juice values for hydrogen ion concentration, volume of secretion, ammonium nitrogen concentration, and urea nitrogen levels during the control periods of observation did not differ significantly. Comparisons of each of these values for the neomycin group with those obtained for the group not given antibiotics yielded 
TABLE I

\begin{tabular}{|c|c|c|c|c|c|c|c|c|}
\hline \multirow{3}{*}{ Study Group ${ }^{2}$} & \multicolumn{6}{|c|}{ GASTRIC JUICE AND BLOOD VALUES FOR CONTROL PERIODS ${ }^{1}$} & \multirow{2}{*}{\multicolumn{2}{|c|}{ Blood }} \\
\hline & \multirow{2}{*}{$\begin{array}{l}\text { No. of } \\
\text { Subjects }\end{array}$} & \multicolumn{5}{|c|}{ Gastric Juice } & & \\
\hline & & $\begin{array}{l}\text { Volume } \\
\text { (ml. per } \\
30 \text { min.) }\end{array}$ & $\begin{array}{l}(H+) \\
(m E q . / l .)\end{array}$ & $\begin{array}{l}N H_{4} N \\
(\mu g . \%)\end{array}$ & $\begin{array}{l}N H_{4} N \\
(\mu g . \text { per } 30 \text { min.) }\end{array}$ & $\begin{array}{l}\text { Urea } N \\
(m g . \%)\end{array}$ & $\begin{array}{l}N H_{a} N \\
(\mu g . \%)\end{array}$ & $\begin{array}{l}\text { Urea N } \\
\text { (mg.\%) }\end{array}$ \\
\hline $\begin{array}{l}\text { No antibiotic } \\
\text { Betazole } \\
\text { NH } 4 \text { Cl i.v. } \\
\text { Urea i.v. } \\
\text { Total group }\end{array}$ & $\begin{array}{r}9 \\
7 \\
8 \\
24\end{array}$ & $\begin{array}{l}37 \pm 6^{3} \\
20 \pm 4 \\
36 \pm 5 \\
32 \pm 4\end{array}$ & $\begin{aligned} 24 & \pm 8 \\
6 & \pm 6 \\
29 & \pm 13 \\
21 & \pm 6\end{aligned}$ & $\begin{array}{r}695 \pm 170 \\
2721 \pm 778 \\
815 \pm 108 \\
1326 \pm 292\end{array}$ & $\begin{array}{l}274 \pm 86 \\
543 \pm 138 \\
293 \pm 57 \\
359 \pm 58\end{array}$ & $\begin{array}{l}74 \\
7 \pm 1 \\
7 \pm 1\end{array}$ & $\begin{array}{l}89 \pm 5 \\
58 \pm 8 \\
73 \pm 9\end{array}$ & $\begin{array}{l}12 \pm 1 \\
15 \pm 2 \\
14 \pm 1 \\
13 \pm 1\end{array}$ \\
\hline $\begin{array}{l}\text { Neomycin treated } \\
\text { NH,Cl i.v. } \\
\text { Urea i.v. } \\
\text { Total group }\end{array}$ & $\begin{array}{r}4 \\
6 \\
10\end{array}$ & $\begin{array}{l}30 \pm 8 \\
30 \pm 7 \\
30 \pm 4\end{array}$ & $\begin{array}{r}14 \pm 4 \\
9 \pm 2 \\
11 \pm 3\end{array}$ & $\begin{array}{l}669 \pm 167 \\
613 \pm 159 \\
635 \pm 105\end{array}$ & $\begin{array}{l}208 \pm 64 \\
196 \pm 89 \\
201 \pm 56\end{array}$ & $\begin{array}{r}8 \pm 4 \\
13 \pm 4 \\
11 \pm 3\end{array}$ & $\begin{array}{l}39 \pm 3 \\
35 \pm 3 \\
36 \pm 2\end{array}$ & $\begin{array}{l}17 \pm 2 \\
17 \pm 2 \\
17 \pm 1\end{array}$ \\
\hline
\end{tabular}

${ }^{1}$ Data obtained during the 30-minute period before betazole hydrochloride (Histalog) administration in subjects given only Histalog and during the 30-minute saline infusion period in the subjects subsequently infused with either ammonium chloride or urea.

${ }^{2}$ Refers to material administered after control period. All subjects given infusions also received Histalog.

${ }^{3}$ Mean \pm standard error of the mean.

'Determined in two subjects.

$\mathrm{p}$ values greater than $0 \cdot 1$ (Snedecor, 1962). However, the mean blood ammonium nitrogen concentration was decreased and the blood urea nitrogen level increased in the neomycin-treated group as compared with the group not given antibiotic $(p<0.05)$ (Snedecor, 1962). These findings may reflect the effect of neomycin on urease-containing organisms in the lower gastrointestinal tract (Gabuzda, 1962).

RESPONSES TO BETAZOLE HYDROCHLORIDE The effects of betazole hydrochloride on volume and hydrogen ion concentration of gastric juice in nine subjects are shown in Table II. These effects were similar to those that occurred in the subjects given infusions, whether or not they were treated with antibiotic (Fig. 1). The responses to betazole hydrochloride were not influenced by oral administration of neomycin or by either the urea or the ammonium chloride infusions.

\section{TABLE II}

EFFECT OF BETAZOLE ALONE ON GASTRIC JUICE AMMONIUM, VOLUME, AND ACIDITY IN NINE SUBJECTS

\begin{tabular}{|c|c|c|c|}
\hline & \multirow{2}{*}{$\begin{array}{l}\begin{array}{l}\text { Before } \\
\text { Betazole }\end{array} \\
-30 \text { to } 0 \\
\text { Minutes }\end{array}$} & \multicolumn{2}{|c|}{ After Betazole } \\
\hline & & $\begin{array}{l}0 \text { to } 30 \\
\text { Minutes }\end{array}$ & $\begin{array}{l}30 \text { to } 60 \\
\text { Minutes }\end{array}$ \\
\hline $\begin{array}{l}\text { Gastric } \mathrm{NH}_{4} \mathrm{~N}(\mu \mathrm{g} . \%) \\
\text { Volume }(\mathrm{ml} \text {. per } 30 \mathrm{~min} .) \\
\text { Gastric } \mathrm{NH}_{4} \mathrm{~N}(\mu \mathrm{g} . \text { per } 30 \mathrm{~min} .) \\
\text { Gastric juice }(\mathrm{H}+)(\mathrm{mEq} . / \mathrm{l} .)\end{array}$ & $\begin{aligned} 695 & \pm 170^{3} \\
37 & \pm 6 \\
274 & \pm 86 \\
24 & \pm 8\end{aligned}$ & $\begin{array}{c}1172 \pm 438 \\
62 \pm 13 \\
649 \pm 286 \\
55 \pm 21\end{array}$ & $\begin{array}{c}773 \pm 227 \\
86 \pm 14 \\
666 \pm 238 \\
93 \pm 17\end{array}$ \\
\hline \multicolumn{4}{|c|}{$\begin{array}{l}\text { 'Each column of data refers to a } 30 \text {-minute collection period. Gastric } \\
\text { acidity was determined on specimens obtained at the end of the } \\
\text { period; the other values were determined on the total volume aspirated } \\
\text { each period. } \\
\text { 'Betazole hydrochloride (Histalog) } 1-1.5 \mathrm{ml} \text {. (50-75 mg.) was given } \\
\text { intramuscularly at the end of the } 30 \text {-minute control collection. } \\
\text { 'Mean } \pm \text { standard error of the mean. }\end{array}$} \\
\hline
\end{tabular}

Betazole hydrochloride alone (Table II) produced an increase in concentration and in total content of ammonium in gastric juice during the first 30 minutes after injection. These changes occurred while the hydrogen ion content and volume of gastric juice were increasing. In the second 30minute period following injection of betazole

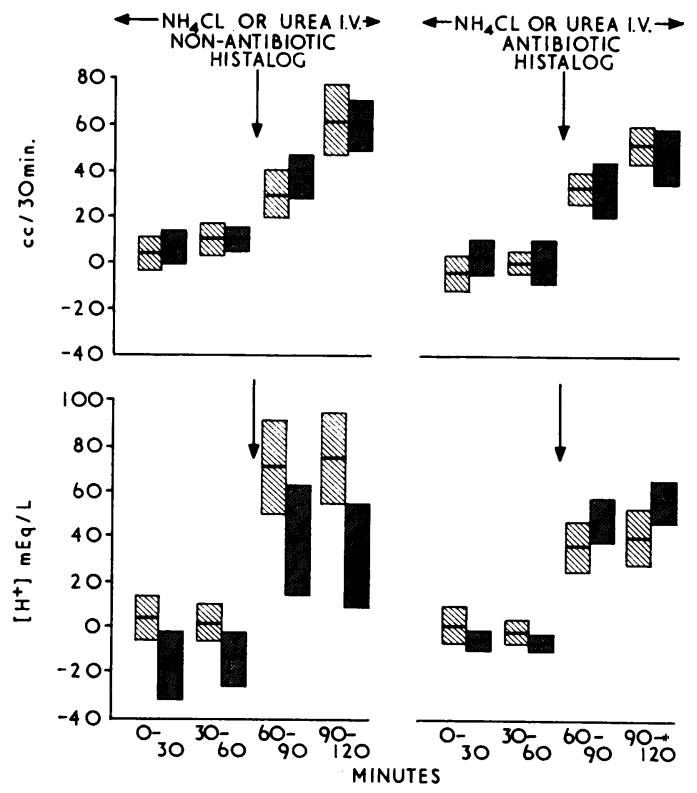

FIG. 1. Change from control values for gastric juice volume (ml./30 min.) and acidity $([\mathrm{H}+] \mathrm{mEq} . / \mathrm{l}$.$) in sub-$ jects given intravenous $\mathrm{NH}_{4} \mathrm{Cl}$ i.v. (a) and in subjects given urea i.v. (:::). The line at the centre of the bar indicates the mean change from control values; the ends of the bar show one standard error above and below the mean. Values for the control periods are in Table I. 


\section{TABLE III}

EFFECT OF $\mathrm{NH}_{4} \mathrm{Cl}$ AND UREA INFUSIONS AND OF BETAZOLE IN SUBJECTS WITH NORMAL GASTRIC SECRETORY FUNCTION

\begin{tabular}{|c|c|c|c|c|c|c|c|}
\hline \multirow[t]{3}{*}{ Study Group } & \multirow{3}{*}{$\begin{array}{l}\text { No. of } \\
\text { Subjects }\end{array}$} & & \multirow{3}{*}{$\begin{array}{r}\text { Intravenous Saline } \\
\text { 0-30 Min. }\end{array}$} & \multicolumn{4}{|c|}{ Intravenous $\mathrm{NH}_{4} \mathrm{Cl}$ or Urea ${ }^{1}$} \\
\hline & & & & \multicolumn{2}{|c|}{ Before Betazole } & \multicolumn{2}{|c|}{ After Betazole } \\
\hline & & & & 30-60 Min. & 60-90 Min. & 90-120 Min. & 120-150 Min. \\
\hline $\begin{array}{l}\mathrm{NH}_{3} \mathrm{Cl} \text { intravenously } \\
\text { No antibiotic }\end{array}$ & 7 & 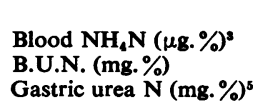 & $\begin{array}{c}89 \pm 54 \\
15 \pm 2 \\
7\end{array}$ & $\begin{aligned} 234 & \pm 17 \\
15 & \pm 2 \\
6 & \end{aligned}$ & $\begin{array}{c}279 \pm 20 \\
15 \pm 2 \\
7\end{array}$ & $\begin{array}{c}305 \pm 28 \\
16 \pm 2 \\
7\end{array}$ & $\begin{aligned} 279 & \pm 25 \\
17 & \pm 2 \\
6 & \end{aligned}$ \\
\hline Neomycin & 4 & $\begin{array}{l}\left.\text { Blood NH.N ( } \mathrm{Ng}_{\mathrm{g}} \%\right) \\
\text { B.U.N. (mg.\%) } \\
\text { Gastric urea N (mg.\%) }\end{array}$ & $\begin{aligned} 39 & \pm 3 \\
17 & \pm 2 \\
8 & \pm 4\end{aligned}$ & $\begin{aligned} 232 & \pm 32 \\
17 & \pm 1 \\
7 & \pm 2\end{aligned}$ & $\begin{aligned} 203 & \pm 24 \\
17 & \pm 2 \\
7 & \pm 2\end{aligned}$ & $\begin{aligned} 209 & \pm 14 \\
18 & \pm 1 \\
7 & \pm 3\end{aligned}$ & $\begin{aligned} 212 & \pm 19 \\
19 & \pm 1 \\
6 & \pm 2\end{aligned}$ \\
\hline $\begin{array}{l}\text { Urea intravenously } \\
\text { No antibiotic }\end{array}$ & 8 & $\begin{array}{l}\text { Blood NH.N ( } \mu \mathrm{g} . \%) \\
\text { B.U.N. mg. \% } \\
\text { Gastric urea N (mg. \%) }\end{array}$ & $\begin{aligned} 58 & \pm 8 \\
14 & \pm 1 \\
7 & \pm 1\end{aligned}$ & $\begin{array}{r}64 \pm 4 \\
23 \pm 3 \\
7 \pm 1\end{array}$ & $\begin{array}{l}66 \pm 5 \\
31 \pm 3 \\
15 \pm 3\end{array}$ & $\begin{array}{l}70 \pm 7 \\
36 \pm 3 \\
18 \pm 2\end{array}$ & $\begin{array}{l}66 \pm 5 \\
44 \pm 4 \\
18 \pm 2\end{array}$ \\
\hline Neomycin & 6 & $\begin{array}{l}\text { Blood NH.N ( } \text { Mg. \%) } \text { B.U.N. (mg. \%) } \\
\text { Gastric urea N (mg. \%) }\end{array}$ & $\begin{array}{l}35 \pm 3 \\
17 \pm 2 \\
13 \pm 4\end{array}$ & $\begin{array}{l}41 \pm 3 \\
32 \pm 2 \\
11 \pm 3\end{array}$ & $\begin{array}{l}45 \pm 4 \\
39 \pm 4 \\
16 \pm 3\end{array}$ & $\begin{array}{l}45 \pm 4 \\
52 \pm 2 \\
33 \pm 6\end{array}$ & $\begin{array}{l}44 \pm 4 \\
61 \pm 3 \\
25 \pm 3\end{array}$ \\
\hline \multicolumn{8}{|c|}{$\begin{array}{l}{ }^{1} \text { Infusions were given at constant rates as follows: saline at } 60 \mathrm{ml} \text {. per hour; } \mathrm{NH}_{4} \mathrm{Cl} \text { (no antibiotic) at } 79 \mathrm{ml} \text {. per hour }(0 \cdot 47 \mathrm{~g} . \text { nitrogen per } \\
\text { hour); } \mathrm{NH}_{4} \mathrm{Cl} \text { (neomycin) at } 60 \mathrm{ml} \text {. per hour }(0 \cdot 36 \mathrm{~g} \text {. nitrogen per hour); urea (no antibiotic) at } 37 \mathrm{ml} \text {. per hour (7.3 g. nitrogen per hour); urea } \\
\text { (neomycin) at } 43 \mathrm{ml} \text {. per hour }(8 \cdot 7 \mathrm{~g} \text {. nitrogen per hour). } \\
\text { 'Betazole hydrochloride (Histalog) } 1-1.5 \mathrm{ml} \text {. ( } 50.75 \mathrm{mg} \text {.) was given intramuscularly } 90 \text { minutes after the start of each experiment. } \\
\text { 'Blood values were determined on specimens obtained at the end of each period; the gastric juice urea values were determined on the total } \\
\text { volume aspirated each period. } \\
\text { 'Mean } \pm \text { standard error of the mean. } \\
\text { 'Metermined in two subjects. }\end{array}$} \\
\hline
\end{tabular}

hydrochloride, gastric juice ammonium concentration returned toward basal values, but total ammonium output remained elevated (Table II).

EFFECT OF AMMONIUM CHLORIDE INTRAVENOUSLY (TABLE III AND FIG. 2) Intravenous administration of ammonium chloride resulted in prompt and sustained elevations of blood ammonium nitrogen levels in all subjects, whether or not pretreated with neomycin. Ammonium concentration and content of gastric juice also increased with ammonium chloride infusions. The effect was similar to that resulting from urea infusions, although 15 times as much nitrogen was given when urea was infused. The increases in both blood and gastric juice ammonium occurred without changes in either blood or gastric juice urea nitrogen levels.

EFFECT OF UREA INTRAVENOUSLY The intravenous infusion of urea produced progressive increases in blood and gastric juice urea nitrogen levels in all subjects regardless of neomycin pretreatment (Table III). The concentrations of urea in gastric juice remained lower than blood levels, amounting to approximately one-third to two-thirds of the levels found in blood. Increases in urea nitrogen concentration of gastric juice were not detectable during the first $\mathbf{3 0}$ minutes of urea infusion, even though blood urea levels were already elevated.
Gastric juice ammonium concentrations increased during the urea infusions (Fig. 2). These infusions were associated with increases in mean blood ammonium nitrogen levels in both the antibiotictreated and untreated groups (Table III). The changes were minimal and all the values were within the accepted range or normal.

EFFECT OF BETAZOLE HYDROCHLORIDE GIVEN DURING AMMONIUM CHLORIDE AND UREA INFUSIONS (FIG. 2) Betazole administration accentuated the increase in gastric juice ammonium concentration during ammonium chloride infusion ( $p<0.05>0.01)$. A similar effect did not occur during the urea infusions ( $p>0.05$ ). Total ammonium nitrogen content of gastric juice was increased significantly $(p<0.01)$ after betazole in both groups as the volume of gastric juice secreted increased.

AMMONIUM CHLORIDE INFUSIONS IN PATIENTS WITH PERNICIOUS ANAEMIA (TABLE IV) Two patients with pernicious anaemia and betazole-fast gastric anacidity were infused with ammonium chloride in a similar manner to that used in the other subjects. The infusions produced sustained elevations of arterial blood ammonium nitrogen levels, but urea nitrogen levels were unchanged. Gastric ammonium nitrogen levels increased. These patients demonstrated the expected poor gastric secretory responses 


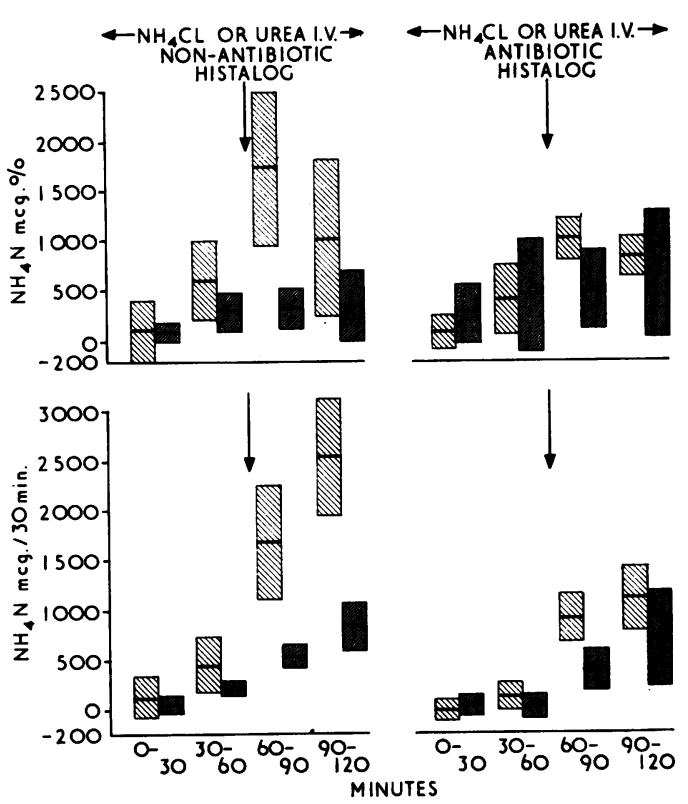

FIG. 2. Change from control values for gastric juice $\mathrm{NH}_{4} \mathrm{~N}$ concentration $(\mu \mathrm{g} . \%)$ and content $(\mu \mathrm{g} . / 30 \mathrm{~min}$.$) in$ subjects given intravenous $\mathrm{NH}_{4} \mathrm{Cl}(\square)$ and in subjects given intravenous urea (:::). The line at the centre of the bar indicates the mean change from control values; the ends of the bar show one standard error above and below the mean. Values for the control periods are in Table I.

to betazole hydrochloride. Minimal, if any, changes in gastric juice ammonium nitrogen concentration and content were noted following betazole administration. Betazole did not induce increases in these values comparable to those observed when ammonium chloride was given to subjects with normal gastric secretory mechanisms.

EFFECT OF GASTRIC ASPIRATION ON BLOOD AMMONIUM LEVELS The possibility that elevated blood am- monium levels in patients with hepatic disease might be influenced by removal of gastric juice was assessed in two patients by administering betazole hydrochloride, $50 \mathrm{mg}$. intramuscularly, at one-hour intervals for two doses. Gastric suction was begun with the first injection and continued for two hours. The values for blood ammonium nitrogen preceding the injections, at the lowest level during the suction, and at one hour following cessation of suction are shown in Table V. Decreases in blood ammonium levels were observed during the aspiration period.

\section{TABLE V}

EFFECT OF ASPIRATING HISTALOG-STIMULATED GASTRIC JUICE ON BLOOD $\mathrm{NH}_{4} \mathrm{~N}$ LEVELS $(\mu \mathrm{g} . \%)$ IN TWO SUBJECTS

\begin{tabular}{lcccc} 
Subject & Control & $\begin{array}{l}\text { During } \\
\text { Suction }\end{array}$ & $\begin{array}{l}\text { One Hour } \\
\text { after Suction }\end{array}$ & $\begin{array}{l}\text { Total Gastric } \\
\text { Juice NH.N } \\
\text { Removed (ug.) }\end{array}$ \\
\hline J.H. & 132 & 69 & 111 & 991 \\
M.M. & 102 & 89 & 107 & 4,601
\end{tabular}

\section{DISCUSSION}

The idea that gastric juice ammonium is derived entirely from blood urea as a result of either bacterial or non-bacterial gastric urease activity is widely accepted. Our studies indicate, however, that blood ammonium per se may be an additional source of gastric ammonium.

Elevation of blood ammonium level and increased gastric secretory activity can be considered as factors involved in promoting transfer of blood ammonium to gastric juice. The influence of raising blood ammonium levels was shown when ammonium chloride given intraveously produced increases in gastric juice ammonium concentration in subjects with normal gastric secretory mechanisms and in patients with gastric achlorhydria (pernicious anaemia). These were similar to the increases result-

\section{TABLE IV}

EFFECT OF $\mathrm{NH}_{4} \mathrm{Cl}$ INFUSION IN TWO SUBJECTS WITH PERNICIOUS ANAEMIA

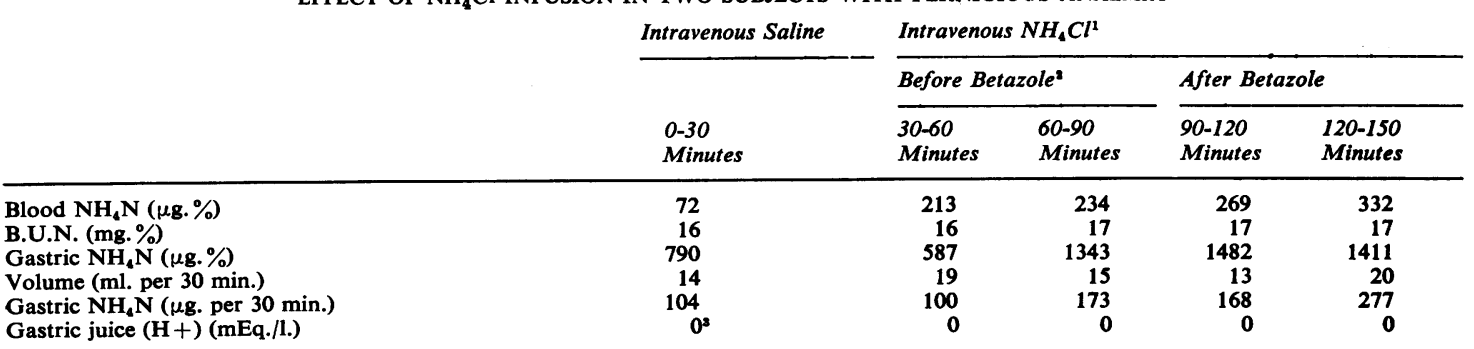

${ }_{1} \mathrm{NH}, \mathrm{Cl}$ infused at constant rate of $90 \mathrm{ml}$. per hour $(0.57 \mathrm{~g}$. nitrogen per hour). No antibiotic was administered.

${ }^{2}$ Betazole hydrochloride (Histalog) $1.5 \mathrm{ml}$. (75 mg.) was given intramuscularly 90 minutes after the start of each experiment.

${ }^{3}$ The measured $p H$ of each gastric juice specimen was greater than 7; the $(\mathrm{H}+)$ was less than 0.0001 mEq./1. 
ing from urea infusions (ammonium chloride vs. urea $p>0 \cdot 1)$ despite the infusion of approximately 15 times as much nitrogen in the urea studies as when ammonium chloride was given. It is unlikely that the ammonium found in gastric juice when $\mathrm{NH}_{4} \mathrm{Cl}$ was infused came solely from hydrolysis of the additional amounts of urea which accompanied increased gastric secretion, since urea infusions resulted in greater concentration and content of gastric urea but lower gastric ammonium levels. The ammonium infusions were not accompanied by changes in either blood or gastric juice urea levels. Accordingly, the elevations in gastric juice ammonium levels probably were not due to synthesis of urea from the administered ammonium and subsequent breakdown by gastric urease.

In normal subjects infused with ammonium chloride, betazole produced rises in gastric juice ammonium concentration $(p<0.05>0.01)$ and content $(p<0.01)$. These occurred in the absence of changes in blood or gastric juice urea nitrogen levels. Betazole administration during urea infusion produced no change in gastric juice ammonium levels $(p>0.05)$, although content increased $(p<0.01)$ as volume increased. These results indicate that elevated blood ammonium and urea produce changes in gastric juice ammonium by different mechanisms. Betazole did not enhance the increase in gastric juice ammonium levels in subjects with pernicious anaemia given ammonium chloride.

The differing effects of betazole in normal subjects compared with those with pernicious anaemia may be explained by trapping of ammonium in acid gastric juice. Ammonia in solution behaves according to the physico-chemical laws applying to other gases in solution, to dissociation of weak acids and bases, and to diffusion across membranes. The ammonia-ammonium buffer system, $\mathrm{NH}_{4}+\rightleftharpoons \mathrm{H}+$ $\mathrm{NH}_{3}$, behaves according to the equation $p \mathrm{H}=p \mathrm{Ka}$ $+\log \frac{\mathrm{NH}_{3}}{\mathrm{NH}_{4}+}$ The $p \mathrm{~K}$ for this system is approximately 9.1 (Bromberg, Robin, and Forkner, 1960). Accordingly, almost all ammonium is in the form of ammonium ion $\left(\mathrm{NH}_{4}+\right.$ ) at the $p \mathrm{H}$ of blood and for practical purposes gastric juice of low $p \mathrm{H}$ can be considered to contain no ammonia $\left(\mathrm{NH}_{3}\right)$. Tissue cell membranes (Jacobs and Parpart, 1938; Jacobs and Stewart, 1936; Stabenau, Warren, and Rall, 1959), probably including gastric mucosa (Shore, Brodie, and Hogben, 1957), are relatively permeable to $\mathrm{NH}_{3}$ and impermeable to $\mathrm{NH}_{4}+$. The $p \mathrm{H}$ gradients between blood and gastric juice favour the diffusion of $\mathrm{NH}_{3}$ into the juice, where, because of the low $p \mathrm{H}$, it would be 'trapped' as $\mathbf{N H}_{4}+$ (ionized, non-diffusable) and be unavailable for reabsorption (Schanker, Shore, Brodie, and Hogben, 1957). The distribution expected for a weak base at the $p \mathrm{H}$ levels of blood and gastric juice may be calculated according to the formula suggested by Brodie (1964). Gastric juice should contain approximately five times the blood concentration of ammonium. The ratios observed in this study of 4-20 to 1 are of the predicted order of magnitude.

Thus, increased diffusion of ammonia in response to increasing blood levels and enhanced transfer and trapping of blood ammonium when gastric secretory activity is stimulated are factors which influence the appearance of ammonium in gastric juice. These mechanisms appear to be independent of urea hydrolysis as a source of gastric juice ammonium. The finding that blood ammonium levels are decreased temporarily by gastric aspiration provides additional evidence that gastric ammonium is derived from blood ammonium. Further studies will be required to evaluate the clinical significance of this observation.

How urea infusions produce increases in gastric juice ammonium is not settled by our data. The possibility that ammonium may have been contaminating the urea infused was considered. This was not the case, since by analysis the urea contained only $1,106 \mu \mathrm{g}$. ammonium nitrogen per $100 \mathrm{ml}$. (range $=812-1791$ ), an amount insufficient to produce the changes observed in all subjects. Even in those in whom the ammonium infused with the urea equalled the increased recovery of gastric juice ammonium, the assumption would have to be made that all of the infused ammonium was recovered in the gastric juice. This is unlikely. Furthermore, no rises in blood ammonium were detected when urea was given. A gastric urease could account for the observed effects. In these studies treatment of the subjects with neomycin before the urea infusions failed to produce significant decreases in basal gastric juice ammonium levels and to inhibit the increase in gastric juice ammonium that occurred when urea was infused. These data favour the possibility that the urease is non-bacterial or, alternatively, that it is in a site not accessible to neomycin.

Hypoacidity of gastric juice in patients with uraemia has been ascribed to a possible neutralizing effect of ammonium in gastric juice (Lieber and Lefèvre, 1959). Induction of great increases in gastric juice ammonium content by ammonium chloride infusions and betazole hydrochloride stimulation had no demonstrable effect on the $p H$ of gastric juice in the patients studied. Although ammonia is a buffer and combines with hydrogen ion to form ammonium, $14 \mathrm{mg}$. of ammonia neutralizes only $1 \mathrm{mEq}$. of hydrogen ion. The magnitude of gastric juice ammonium values reported in this study and 
by others (Kornberg and Davies, 1955; Mossberg et al., 1963) makes it unlikely that the ammonium content of gastric juice is sufficiently high to have a significant neutralizing action in human subjects with normal gastric secretory function. Infusion of very large quantities of urea $(45-90 \mathrm{~g}$.) also failed to decrease gastric acidity consistently although large increases in gastric juice ammonium were observed in some subjects (Mossberg et al., 1963). Thus, the conclusions of Lieber and Lèfevre (1959) concerning the role of elevated gastric juice ammonium levels in producing hypoacidity in patients with uraemia were not confirmed by Mossberg et al. (1963) or by the studies reported here. The reasons for this discrepancy are not evident, but they may be related to differences between the uraemic syndrome and induced azotaemia as shown experimentally in dogs (Fishbein, Rush, Wilder, and Murphy, 1964).

Much evidence, including some of the data presented here, favours the possibility that gastric ammonium is produced from blood urea through the action of a non-bacterial gastric urease. Our studies demonstrate that ammonium in gastric juice also originates from blood ammonium and is related, in part at least, to transfer of ammonia from blood into juice. The magnitude of this diffusion depends upon blood ammonium level, the $p \mathrm{H}$ gradient between blood and gastric juice, and the state of gastric secretion. The relative significance of blood urea and blood ammonium in determining gastric ammonium content is difficult to evaluate. The amount of gastric juice ammonium derived through each mechanism may be conditioned by various physiological states and by different diseases.

\section{SUMMARY}

The effects of ammonium chloride and urea infusions on gastric juice ammonium and urea levels and on the secretory response to betazole hydrochloride were compared. Volume and acidity of gastric juice secreted in response to betazole were not modified by elevation of blood or gastric juice urea or of blood or gastric juice ammonium concentrations. The role of ammonium in neutralizing normal human gastric juice appears to be minimal.

Ammonium chloride and urea infusions produced similar increases in gastric juice ammonium even though the nitrogen content of the infused urea was 15 times greater. Urea infusion produced increases in gastric juice ammonium without changing blood ammonium levels, confirming previous reports that blood urea is a source of gastric juice ammonium. Betazole hydrochloride did not augment the rise in gastric juice ammonium content resulting from urea infusion. Pretreatment with neomycin did not alter the effect of urea in increasing gastric juice ammonium, thus favouring the idea that the breakdown of blood urea is by a tissue rather than bacterial urease.

Ammonium chloride infusion raised blood and gastric juice ammonium levels without affecting blood or gastric juice urea levels. The transfer of ammonia from blood to gastric juice was accelerated by stimulation of gastric secretory activity by betazole. The hypothesis is advanced that gastric juice ammonium is derived in part from blood ammonium and that ammonia diffuses into and is trapped in the acid gastric juice. The relative contribution of blood urea and blood ammonium in determining gastric ammonium content is unknown.

\section{REFERENCES}

Bessman, S. P., and Stauffer, J. C. (1957). Factors affecting the appearance of ammonia in the gastric juice. J. clin. Invest., 36, 875.

Brodie, B. B. (1964). Absorption and Distribution of Drugs, p. 24. Williams \& Wilkins, Baltimore.

Bromberg, P. A., Robin, E. D., and Forkner, C. E., Jr. (1960). The existence of ammonia in blood in vivo with observations on the significance of the $\mathrm{NH}_{\mathbf{4}}+-\mathrm{NH}_{\mathbf{3}}$ system. J. clin. Invest., 39, 332-341.

Conway, E. J. (1957). Microdiffusion Analysis and Volumetric Error. Crosby Lockwood \& Son, London.

_, FitzGerald, O., McGeeney, K., and Geoghegan, F. (1959). The location and origin of gastric urease. Gastroenterology, 37, 449-456.

Fishbein, R., Rush, B. F., Jr., Wilder, R. J., and Murphy, G. P. (1964). Changes in gastric secretion. Arch. Surg., 89, 273-274.

FitzGerald, O., and Murphy, P. (1950). Studies on the physiological chemistry and clinical significance of urease and urea with special reference to the stomach. Irish J. med. Sci., 292, 97-159.

Gabuzda, G. J. (1962). Hepatic coma: clinical considerations, pathogenesis and management., Advanc. intern. Med., 11, 11-73.

Glasstone, S., and Lewis, D. (1960). Elements of Physical Chemistry, p. 509. Van Nostrand, Princeton. N.J.

Jacobs, M. H., and Parpart, A. K. (1938). Osmotic properties of the erythrocyte: on the permeability of the erythrocyte to ammonia and the ammonium ion. J. cell. comp. Physiol., 11, 175-192.

, and Stewart, D. R. (1936). The distribution of penetrating ammonium salts between cells and their surroundings. Ibid., 7, 351-365.

Kornberg, H. L., and Davies, R. E. (1955). Gastric urease. Physiol. Rev., 35, 169-177.

Lieber, C. S., and Lefèvre, A. (1959). Ammonia as a source of gastric hypoacidity in patients with uremia. J. clin. Invest., 38, 12711277.

Moore, E. W. (1963). Gastric juice $p H$ measurements. Gastroenterology 45, 458-460.

Mossberg, S. M., Thayer, W. R., Jr., and Spiro, H. M. (1963). Azotemia and gastric acidity: the effect of intravenous urea on gastric acid and gastric ammonium production in man. J. Lab. clin. Med., 61, 469-475.

Nathan, D. G., and Rodkey, F. L. (1957). A colorimetric procedure for the determination of blood ammonia. J. Lab. clin. Med., 49, 779-785.

Rappoport, W. J., and Kern, F., Jr. (1963). Gastric urease activity in normal subjects and in subjects with cirrhosis. Ibid., 61, 550-559.

Rosenthal, H. L., (1955). Determination of urea in blood and urine with diacetylmonoxime. Analyt. Chem., 27, 1980-1982.

Schanker, L. S., Shore, P. A., Brodie, B. B., and Hogben, C. A. M. (1957). Absorption of drugs from the stomach. I. The rat. J. Pharmacol. exp. Ther., 120, 528-539. 
Shore, P. A., Brodie, B. B., and Hogben, C. A. M. (1957). The gastric secretion of drugs: a $p \mathrm{H}$ partition hypothesis. Ibid., 119, 361-369.

Skeggs, L. T., Jr. (1957). An automatic method for colorimetric analysis. Amer. J. clin. Path., 28, 311-322.

Snedecor, G. S. (1962). Statistical Methods. Iowa State University Press, Ames.

Stabenau, J. R., Warren, K. S., and Rall, D. P. (1959). Role of $p H$ gradient in the distribution of ammonia between blood and cerebrospinal fluid, brain, and muscle. $J$. clin. Invest., 38 , 373-383.
Von Korff, R. W., Ferguson, D. J., and Glick, D. (1951). Role of urease in the gastric mucosa. III. Plasma urea as source of ammonium ion in gastric juice of histamine-stimulated dog. Amer. J. Physiol., 165, 695-700.

-, and Glick, D. (1951). Role of urease in the gastric mucosa. II. In vitro studies with isotopic urea on frog mucosa. Ibid., 165, 688-694.

Webster, L. T., Jr., Davidson, C. S., and Gabuzda, G. J. (1958), Effect on portal blood ammonium of administering nitrogenous substances to patients with chronic hepatic disease. J. Lab. clin. Med., 52, 501-514. 